\title{
THE ROLES OF MANAGEMENT AND SHAREHOLDERS IN CORPORATE GOVERNMENT
}

\author{
Frank D. EMERson*
}

\section{INTRODUCTION}

Following its emergence as a legal entity, the corporation rapidly has come to exhibit characteristic behavior patterns. ${ }^{1}$ Some of these reflect its contacts with other societal institutions; some, its internal functioning. While the former have vital consequences for the law generally, they are ordinarily beyond and only indirectly affect the traditional field of corporation law. With respect to the latter, however, corporation law, and in particular the roles it defines for management and shareholders, is directly involved.

The title of this symposium suggests the thesis that corporation law today has, in a number of areas, developed a "new look." The specific questions here posed for consideration are: Is a "new look" to be found in the relative positions in which present-day statutes cast management and shareholders; and, if so, in what respects does it differ from prior modes? And more important for society generally, in so far as data have been collected, does this "new look" harmonize with current corporate behavior? Is it likely to conduce socially desirable management and shareholder behavior?

Answers to these questions may be sought by examining the provisions of contemporary corporation statutes defining the powers of management and shareholders, noting current characteristics of corporate behavior, and evaluating the former in light of the latter.

\section{I}

LAw

In an effort to ascertain the nature and extent of the management-shareholder "new look" as enacted into sections of contemporary corporation statutes, it is proposed first to note the provisions applicable to management and then those relating to shareholders. While the so-called Model Business Corporation Act, as prepared, publicized, and otherwise promoted by the Committee on Corporate Laws of the American Bar Association has been critically commented upon by a number

-A.B. 1938, University of Akron; LL.B. 1940, Western Reserve University; Kenneson Fellow, Summers 1955-57, LL.M. I957, and candidate for J.S.D., New York University. Member of the Ohio bar; Professor of Law, University of Cincinnati. Co-author, [with Franklin C. Latcham] SHAREHoLdeR Democracy: A Broader Outzook for Corporattons (r954). Contributor to legal periodicals.

${ }^{1}$ See Adolf A. Berle, Jr., The 20 th Century Capttalist Revolution (1954); Adolf A. Berle, Jr., and Gardiner C. Means, The Modern Corporation and Private Property (i932). 
of persons, ${ }^{2}$ the fact that since $195 \mathrm{I}$ it has been adopted substantially in toto by seven jurisdictions ${ }^{3}$ strongly suggests that it must be regarded as exemplifying contemporaneous corporation statutes. ${ }^{4}$ For purposes of delineating and distinguishing its "new look," it may be compared with the Uniform Business Corporation Act," approved nearly thirty years ago by the Commissioners on Uniform State Laws. Although the Uniform Act has been adopted by only four states, ${ }^{\circ}$ this may, in large part, be attributable to the fact that the Commissioners, unlike the American Bar Association, make no active effort to obtain passage of their proposed legislation.

\section{A. Management Provisions}

The Uniform Act, like many other corporation statutes, provides that "the business of every corporation shall be managed by a board of . . . directors. . .."7 Similarly, the Model Act states "the business and affairs of a corporation shall be managed by a board of directors." If inquiry were to cease with consideration of these provisions, the conclusion would be inescapable that thirty years have brought no "new look" to the management-shareholder sector. In fact, it could logically be observed that the very breadth and scope of these provisions make it difficult to imagine how more sweeping powers could be conferred on management. Indeed, other considerations aside, their all-inclusive language might even suggest that if any changes were to be expected, they could only take the form of limitations on management's powers. This has not been the case, however, and management powers continue to be extensive, as they always have been and as, perhaps, they always must be.

What, then, of the shareholder provisions of the Uniform and Model Acts?

\section{B. Shareholder Provisions}

Analysis of the shareholder provisions of the two acts may be approached from the standpoint of the expression they give to the traditional rights of the shareholder to elect directors and vote fundamental changes. To these there may also be added

${ }^{3}$ Wright, Current Developments in Statutory Corporation Law, 7 MinM L. Q 1, 6-13 (1952); Harris, The Model Business Corporation Act-Invitation to Irresponsibility? $50 \mathrm{Nw}$. U. L. REV. I (1955); Dykstra, Gaps, Ambiguities, and Pitfalls in the Utah Corporation Code, 4 UTAH L. Rev. 439, 455 (1955); Emerson, Vital Weaknesses in the New Virginia Corporation Law and the Model Act, 42 VA. L. REv. 489 (1956); Emerson and Latcham, Law and the Future: Corporation Law, 5 I Nw. U. L. Rev. 196, $199-200$ (1956).

${ }^{3}$ They are: Wisconsin (1951), Oregon (1953), District of Columbia (1954), Texas (1954), Virginia (1956), North Dakota (1957), and Colorado (1958).

- Two states recently revised and amended their corporation statutes extensively, but did not adopt the Model Act. They are: North Carolina (1957) and Ohio (1955). See Latty, Powers, and Breckenridge, The Proposed North Carolina Business Corporation Act, 33 N.C. L. Rev. 26 (1954); Emerson, The New Olio General Corporation Law: Some Comments and Some Comparisons, 24 U. Cin. L. REv. 463 (1955): The North Carolina statute is an especially excellent piece of work.

${ }_{5}$ U.L.A. II5 (1957). This Act has since been redesignated a model act, but to obviate confusion, it will be referred to hereinafter as Uniform Business Corporation Act.

'They are: Louisiana (1928), Idaho (1929), Washington (1933), and Kentucky (1946). 9 U.L.A. 115 (1957).

7 Uniform Business Corporation Act $\$ 3$ I-I.

${ }^{8}$ MOdel Business Corporation ACt $\$ 33$. 
the obligation of disclosure to and the right of participation by shareholders. While another traditional right of the shareholder is his right to receive dividends, it may be excluded from consideration, in light of the fact that dividends are the subject of another article in this symposium. ${ }^{9}$

\section{x. Election of directors}

Crucial here is the method by which shareholders may elect or remove directors and the nature and extent of any limitations upon their voting rights. This involves the matters of straight and cumulative voting, the frustration of cumulative voting by such devices as classification ${ }^{10}$ and reduction in the number of directors, and the requirements for removal of directors.

The Uniform Act unqualifiedly provides for cumulative voting, ${ }^{11}$ and renders it impossible for management to deprive shareholders of this right by means of articles or charter restrictions or otherwise. The Model Act also initially provided for mandatory cumulative voting, ${ }^{12}$ but optional provisions for so-called permissive cumulative voting were adopted in $19555^{13}$ In this regard, therefore, the Model Act has a different, although hardly a "new" look, in that it alternatively contemplates only straight voting and the resultant absence of board representation for minority shareholders.

Apart from denying it by charter or articles provisions, cumulative voting may also effectively be vitiated by classification of directors and reduction of their number. The Uniform Act does not expressly recognize these techniques, but the Model Act specifically allows the former ${ }^{14}$ and, moreover, affords no protection against the latter. It is, thus, apparent that cumulative voting not only may be denied shareholders under the Model Act, but, even where granted, may be seriously limited as a consequence of possible classification and reduction in the number of directors. These Model Act provisions, furthermore, diverge philosophically from the statutes requiring annual election of directors ${ }^{15}$ and permitting reduction in their number, as in the case of their removal, ${ }^{16}$ only with appropriate safeguards for cumulative voting. ${ }^{17}$

Although the Uniform Act provides for special meetings of shareholders, ${ }^{18}$ it contains no provision for the removal of directors without cause, a matter of basic importance to shareholders, ${ }^{19}$ as does the Model Act. ${ }^{20}$

${ }^{\circ}$ Garrett, Capital and Surplus Under the New Corporation Statutes, infra 239.

${ }^{10}$ Classification of directors is frequently referred to as the "stagger system." See LEwis D. GiLberT, DIVIDENDS AND DEMOCRACX I89-91 (I956).

12 Uniform Business Corporation Act $\S 28$-III.

${ }^{13}$ Model Business Corporation Act $\$ 31$.

${ }^{13}$ Id. $\S 3 \mathrm{IA}$.

${ }^{16}$ Cf. Cal. Corp. Code $\$ 805$; Ala. Code tit. io, $\$ 23$ (1940); Wyommg Comp. Stat. Ann. $\$ 44$-Iog (1945).

${ }_{10}$ Cf. Ohio Rev. Code Ann. $\$$ ror.58(C) (Page Supp. 1956).

${ }^{17}$ Cf. Mich. Comp. Laws $\$ 450.13$ (3) (1948); N.C. GeN. Stat. 55-25(b) (Supp. 1955).

${ }^{18}$ UniforM Business CORPoration Act $\$ 27$-II.

${ }^{10}$ See Henry W. Ballentine, Corporations 435 (1946).

${ }^{20}$ Model Business Corporation Act $\S 36$ A. 
Little that is modern, then, has been supplied by the Model Act's "new look" with respect to the election of directors. For the most part, the Model Act's sections, either directly or optionally, restrict or fail adequately to protect this basic shareholder right.

\section{Fundamental changes}

The Uniform Act affords shareholders the right to amend the articles of incorporation. ${ }^{21}$ It also empowers them to amend the bylaws and expressly provides that director amendment of bylaws is "subject to the power of the shareholder to change or repeal such by-laws."22 As a further shareholder safeguard, it provides, in addition, that the directors shall not make or alter any bylaw fixing their "qualifications, classification, term of office or compensation."23

Under the Model Act, by way of contrast, the articles or charter may be amended only if the board of directors has adopted a resolution setting forth the proposed amendment. ${ }^{24}$ It is also expressly stated that "the power to alter, amend or repeal the by-laws or adopt new by-laws shall be vested in the board of directors unless reserved to the shareholders by the articles of incorporation." ${ }^{25}$ Here, it is apparent that the Model Act has, indeed, a distinctly "new look," in that it imposes substantial limitations upon shareholders with respect to their traditional rights to initiate and to achieve fundamental changes and to amend the corporate bylaws. ${ }^{26}$

The Model Act, furthermore, substantially diminishes stockholder rights in the case of management-initiated fundamental changes. While the Uniform Act accords dissenters' rights in the event of sale, lease, or exchange of the corporation's assets, merger, consolidation, or other fundamental changes, ${ }^{27}$ the Model Act provides merely for class voting on amendments of the articles or charter, without regard to whether they involve fundamental changes, ${ }^{28}$ and accords dissenters' rights only in the event of a sale or mortgage of assets in the regular course of business, a merger, or a consolidation. ${ }^{29}$

Dissenters' rights, like charter and bylaw amendments, it is plain, receive more restrictive treatment under the Model Act than under the Uniform Act. Again, shareholder protection is sacrificed, and wider powers are given to management.

\section{Disclosure and participation}

Basic to the effective exercise of the shareholder's traditional rights respecting both election of directors and fundamental changes is his right to receive information

${ }^{21}$ UnIform Business Corporation ACt $\$ 38-\mathrm{I}$.

${ }^{29} \mathrm{Id}$. $\$ 26-\mathrm{I}$ and II. $\quad{ }^{23} \mathrm{ld}$. $\$ 26-\mathrm{III}$.

${ }^{24}$ Model Business Corporation Act $\$ 54(\mathrm{a}) . \quad{ }^{25} I d . \$ 25$.

${ }^{20}$ See Emerson, Vital Weaknesses in the New Virginia Corporation Law, 42 VA. L. Rev. 489, $51 \mathrm{r}-\mathrm{x} 3$, 527-28 (1956); Note, Exclusive Control of the Adoption and Amendment of By-Laus or Regulations by the Corporate Directors, 25 U. CiN. L. REv. 362 (1956).

${ }^{27}$ Uniform Business Corporation ACT $\$ \$ 42,48$.

${ }^{28}$ Model Business Corporation Act $\$ 55$; see also Emerson, Vital Weaknesses in the New Virginia Corporation Law, 42 VA. L. REv. 489 (1956).

${ }^{20}$ Model Business Corporatton Act $\$ \$ 7$ T, 74 . 
and to participate in corporation affairs. Disclosure and participation are also matters of importance in connection with submission of shareholder proposals, ${ }^{30}$ the conduct of proxy contests, ${ }^{31}$ and the prosecution of derivative suits. These matters may be viewed in the context of the provisions for inspection of books and records, availability of shareholder voting lists, and dissemination of financial statements. ${ }^{32}$

The Uniform Act gives to every shareholder a substantially unencumbered right "to examine, in person or by agent or attorney, at any reasonable time or times, for any reasonable purpose, the share register, books of account and records of the proceedings of the shareholders and directors and to make extracts therefrom." ${ }^{33}$ The Model Act contrasts sharply, in that it provides, as do the statutes of a few states, that a shareholder to be entitled to inspect must have been a holder "of record for at least 6 months immediately preceding his demand or ... the holder of record of at least $5 \%$ of all the outstanding shares." ${ }^{34}$ Moreover, while the Model Act provides that a voting list shall be made available to shareholders, ${ }^{35}$ the ten-day limit on availability is so short as to render meaningless the original intention of the voting-list statutes-namely, to facilitate communication among shareholders. ${ }^{30}$

The Uniform Act provides for the filing of annual reports with "adequate information as to the financial condition of the corporations." ${ }^{37}$ The Model Act requires the mailing to shareholders, on written request, of the corporation's "most recent financial statements showing in reasonable detail its assets and liabilities and the results of its operations." ${ }^{38}$ To the extent that the Model Act's section requires dissemination of financial statements, it represents a noticeable advance over the Uniform Act. Both acts, however, are extremely vague as to such matters as the management's time limit for furnishing shareholders financial statements, as well as to the form and content of those provided.

In summary, therefore, the Model Act seriously abridges the shareholder's inspection rights, is quite outdated in its voting-list availability provisions, and is both vague and inadequate with respect to the furnishing of financial information. As has already been pointed out, the "new look" in the Model Act also limits

${ }^{30}$ See Ledes, Emerson, Freeman, Gilbert, Bayne, and Slavin, Proper Subject: A Symposizm, $34 \mathrm{U}$. DET. L. J. 517 (1957).

${ }^{31}$ See Bayne and Emerson, The Virginia-Carolina Chemical Corporation Proxy Contest: A Case Study of the SEC's New Rule 240.14a-11 and Schedule 14B, 57 Colum. L. Rev. 80x (1957); Frank D. Emerson and Frankin C. Latcham, Shareholder Democracy: A Broader Outrook for CorporaT7ows 5I-70 (1954) (concerning the Sparks-Withington proxy contest).

${ }^{32}$ For a comparative analysis of the law in England, Canada, South Africa, France, and Brazil respecting these matters, see Emerson, The Comparative Position of the Minority Shareholder in Selected Cotntivies, 3 How. L.J. 86 (1957).

${ }^{33}$ Uniform Business Corporation ACt $\$ 35$-IV.

${ }^{36}$ Model Business Corporation ACt $\$ 46$.

${ }^{35} I d . \S 29$.

${ }^{30}$ See Magill v. North American Refractories Co., 128 A.2d 233 (Del. Sup. Ct. 1956), 129 A.2d 4 II (Del. Sup. Ct. 1957); Note, Shareholder Voting List Statutes-Are They Effective?, 26 U. CIN. L. Rev. 288 (1957); and Emerson, Vital Weaknesses in the New Virginia Corporation Law, 42 VA. L. Rev. 489,513 (r956).

${ }^{37}$ Unafora Business Corporation Act $\$ 36$.

${ }^{38}$ Model Business Corporatton ACt $\$ 46$. 
the shareholder's right to elect directors, restricts or eliminates his rights in connection with fundamental changes, and impairs his right to amend the bylaws. These developments would suggest that corporate behavior conforms to requisite high standards and that safeguards and limitations on managerial powers are not needed. It remains to inquire into whether, in fact, this is so.

II

\section{BEHAVIOR}

Several recent studies have concerned themselves with corporate officers, junior executives, and corporate power and its philosophical implications. Their observations, insights, and distilled conclusions, therefore, may, perhaps, afford a valid basis for evaluating the emerging statutory treatment of management-shareholder relationships.

\section{A. Corporate Officers}

The Big Business Executive ${ }^{39}$ is an interesting starting point, for it presents a composite profile, drawn from a survey, of the chief executive of the business corporations. Typically, while still relatively young and inexperienced, he obtained a minor position with the corporation. Gradually, he worked up, through operations or production, to a vice-presidency, from which he was promoted to the presidency at the age of fifty-two. Although he has specialized professional training, he has never practiced independently, nor has he at any time run a business of his own, as his father did. He is a business administrator-a bureaucrat-with little job experience outside his own corporation. His investment in his company is nominal, usually less than .I per cent of the outstanding stock. He is sixty-one years of age and will probably be seventy when he retires.

Professor Newcomer feels that this profile differs in at least three respects from the ideal. ${ }^{40}$ First, the president is usually named from among the corporation's officers, probably without sufficient consideration of possibly better talent available elsewhere. Secondly, the chief executive is a specialist in engineering, law, or perhaps some other field not directly related to his job of administration. Thirdly, he is not appointed until he has reached an age too old to permit an extended period of administration prior to retirement. Professor Newcomer also finds evidence that these shortcomings may be matters of importance in the circumstance that the qualifications of executives of fast-growing companies came closer to the ideal than those of slow-growing companies.

Findings of another survey are generally similar. In Big Business Leaders in America, it is stated that "the typical career pattern is a bureaucratic one in business today, just as the typical business organization is primarily bureaucratic."41 Careers, it is said, are built largely on formal education, acquisition of management skills

${ }^{3}$ MABel Newcomer, THE Big Business EXecutive 149-50 (I955).

${ }^{10}$ Ibid.

aI William L. Warner and James C. Abegglen, Big Business Leaders in Axierica 215-16 (1955). 
in the white-collar hierarchy, and movement through the far-flung systems of technicians and lower-level management personnel into top management.

Another writer draws some additional conclusions of an obviously provocative character. In The Power Elite, a Columbia University sociology professor asserts that corporate chief executives and other members of the power elite of America have no ideology, feel the need of none, rule "naked of ideas," and "manipulate without attempted justification." "It is this mindlessness," the reader is told, "that is the true higher immorality of our time; for, with it, there is associated the organized irresponsibility that is today the most important characteristic of the American system of corporate power." ${ }^{\text {42 }}$

\section{B. Junior Executives}

Behavior data relating to the junior executive is also pertinent. On the basis of the surveys already referred to, a corporation's junior executives of today provide its chief executive of tomorrow. And in the meantime, they have an opportunity to participate in corporate decision-making and policy-formation.

The corporate junior executive, with other employees of large organizations, was examined in considerable detail in The Organization Man. He emerges there as overly imbued with an attitude of cooperation and little disposition to critical analysis. He is seen as "denying that there is-or should be-a conflict between the individual and organization," and this is regarded by the author as both "bad for the organization," and "worse for the individual," because "in soothing him," it "robs him of the intellectual armor he so badly needs." Fault is also found with the "denial that there is a conflict between the individual and society," for, as the author points out, "it is the price of being an individual that he must face these conflicts," and "in seeking an ethic that offers a spurious peace of mind ... does he tyrannize himself."

\section{Power and Responsibility}

Two other recent volumes deal in particular with the issues of power and responsibility in the corporate world. In one, Power and Morality in a Business Society, ${ }^{44}$ the authors, having disposed of conscience alone as a solvent, ${ }^{45}$ argue for a taming of power by resort to reason and human association. In developing their theme, particularly in articulating the concept of human association, the authors call for participation by "small, independent groups," even if they tend to be "selfcentered and oblivious to the larger good of the community." They serve, it is asserted, a social good, principally in three ways: (I) retarding resort to technical

${ }^{4}$ Charles W. Mills, The Power Elite 342 (I956).

¿ William H. Whyte, Jr., The Organization Man i4-15 (1956).

"Sylvia K. Selekman and Benjamin M. Selekman, Power and Morality in a Business Society 99, I29, 134 (1956).

"See also Adolf A. Berle, Jro, The 20th Century Capitalist Revolution 6i-1 55 (1954); Emerson and Latcham, Law and the Future: Corporation Law, 5I Nw. U. L. REv. I96 204-05 (I956); Selekman and Selerman, op. cit. supra note 44, at 93-96; Walton H. Hamilon, The Politics of INDUSTRY 137-42 (1957). 
decisions by their concern for efficiency, costs, and profits; (2) restraining authority and forestalling capricious and arbitrary supervision; and (3) deterring power drives of individuals who might exploit for selfish purposes.

The Politics of Industry, the most recent of the several publications referred to, follows a description of the actual modes of power and behavior in modern society, with a concluding chapter summing up the contributions of conscience, commission, and competition as levers operating upon the exercise of power. The author finds that, while today's economy invites regulation, it is imperative that "the minority" be allowed to have its chance, and that there be a thousand points in the larger system at which creative thought and effort may be applied."46

\section{Conclusion}

Contemporary corporation statutes, as exemplified by the Model Act, do not, it is submitted, accord with the realities and needs of our society. At a time when management power is widely regarded as becoming increasingly dominant, the Model Act is substantially restricting the rights of shareholders democratically to participate in corporate affairs. The provisions of the Uniform Act, drafted nearly thirty years ago, are, in a number of respects, more nearly in harmony with the available data bearing on current corporate behavior.

${ }^{10}$ HaMaLToN, op. cit. supra note 45 , at $16 \%$. 